\title{
Osmotic Stress Induces the Expression of VvMAP Kinase Gene in Grapevine (Vitis vinifera L.)
}

\author{
Samia Daldoul, ${ }^{1,2}$ Michael Hoefer, ${ }^{2}$ and Ahmed Mliki ${ }^{1}$ \\ ${ }^{1}$ Laboratoire de Physiologie Moléculaire des Plantes, Centre de Biotechnologie, B.P. 901, 2050 Hammam Lif, Tunisia \\ ${ }^{2}$ AlPlanta-Institute for Plant Research, RLP AgroScience GmbH, 67935 Neustadt, Germany
}

Correspondence should be addressed to Samia Daldoul, samiabiotech@yahoo.fr

Received 29 July 2011; Revised 14 October 2011; Accepted 3 November 2011

Academic Editor: Andrew Wood

Copyright (C) 2012 Samia Daldoul et al. This is an open access article distributed under the Creative Commons Attribution License, which permits unrestricted use, distribution, and reproduction in any medium, provided the original work is properly cited.

\begin{abstract}
Abiotic stress adversely affects the growth of grapevine plants. In order to study the early expression changes of genes particularly involved in signal transduction upon salt and drought stresses in grapevines, ESTs derived from a suppressive subtractive hybridization approach (SSH) were selected for expression studies. We were particularly interested in the expression behaviour of the MAP kinase cDNA clone identified by differential screening of the salt-stressed SSH libraries. Interestingly, VvMAP kinase transcript showed a differential expression towards salt and drought treatment in the salt tolerant cultivar Razegui. The upregulation of this transcript was confirmed by RNA blot analysis. Our results revealed that the VvMAP kinase gene could be classified as an osmotic stress responsive gene as its expression was induced by salinity and drought. Furthermore, our study provides the basis for future research on the diverse signaling pathways mediated by MAPKs in grapevine.
\end{abstract}

\section{Introduction}

Salt and drought stresses are a severe constraint to crop production, and plants that undergo water deficit manifest a wide range of behaviors, ranging from high sensitivity to tolerance.

Grapevine (V. vinifera L.) is economically important for Tunisian agriculture but, due to climate variability and environmental changes, yield and quality of the commonly grown grapevine varieties are impaired. Although the responses of plants to osmotic stress have been extensively studied at the physiological and biochemical levels, the perception and intracellular transmission mechanisms remain largely unknown. Due to their sessile habit, plants are exposed to a variety of environmental stresses. Thus, their responses and adaptation to environmental constraints must be communicated in a specific manner from outside of the cell to the inside, and ultimately to the nucleus, where changes in gene expression may occur. Therefore, plant adaptation to salinity requires the regulation of the expression of various genes which could encode for protein kinases and phospholipases, or transcription factors. Mitogen-activated protein kinases (MAPKs) are one of the important proteins involved in the signal transduction of extracellular information to intracellular targets and play a crucial role in the response to biotic and abiotic stresses [1]. Several plant protein kinases were found to be activated by osmotic stress [2]. It was shown that only one specific MAPK is activated by cold and drought stress in alfalfa plants (N6). Several MAP kinases were identified from different plant species such as tobacco [3], tomato [4], alfalfa [5], maize [6], wheat [7], and barley [8]. In silico studies have shown that MAP kinases belong to a gene family of 12 members of grapevine MAP kinase genes which have evolved by segmental duplication rather than by tandem amplification [9]. To promote crop productivity, it is necessary to improve our knowledge on the gene expression and regulation under osmotic stress. A general assumption has been that stress upregulated genes may be important for stress tolerance [10-12].

So far, a physiological assessment identified the Tunisian Razegui cultivar as salt tolerant [13-15]. This cultivar has been chosen for SSH cDNA library construction in order to characterize and exploit the major genes involved in the tolerance against salinity. In this study, we were specifically 
interested in the expression analysis of one candidate gene, MK5, identified as differentially expressed under salt and drought stresses.

\section{Material and Methods}

2.1. Plant Culture and Stress Treatments. Cultivar Razegui (Vitis vinifera L.) was grown using the hydroponic system in a controlled greenhouse $\left(25^{\circ} \mathrm{C} / 20^{\circ} \mathrm{C}\right.$ temperature, $16 / 8 \mathrm{~h}$ photoperiod and the relative humidity "RH" 60\%). Nutritive solution was composed of $\mathrm{Ca}\left(\mathrm{NO}_{3}\right)_{2}=3.5 \mathrm{M}, \mathrm{KNO}_{3}=3 \mathrm{mM}$, $\mathrm{NH}_{4} \mathrm{NO}_{3}=2 \mathrm{mM}, \mathrm{K}_{2} \mathrm{HPO}_{4}=0.6 \mathrm{mM}, \mathrm{MgSO}_{4}=1.5 \mathrm{mM}$, $\left(\mathrm{NH}_{4}\right)_{2} \mathrm{SO}_{4}=2.8 \mathrm{mM}, \mathrm{KH}_{2} \mathrm{PO}_{4}=1.6 \mathrm{mM}$, Fe-EDTA = $90 \mu \mathrm{M}, \mathrm{MnCl}_{2}=9 \mu \mathrm{M}, \mathrm{ZnSO}_{4}=0.76 \mu \mathrm{M}, \mathrm{CuSO}_{4}=0.70 \mu \mathrm{M}$, $\mathrm{H}_{3} \mathrm{BO}_{3}=46.27 \mu \mathrm{M}, \mathrm{KI}=0.43 \mathrm{mM}$, and $\left(\mathrm{NH}_{4}\right)_{6} \mathrm{MO}_{7} \mathrm{O}_{24}=$ $0.21 \mu \mathrm{M}$ with $\mathrm{pH}$ 6.0. Gradual salt stress was imposed. $\mathrm{NaCl}$ concentrations were brought up to $100 \mathrm{mM}$ by increments of $25 \mathrm{mM} \mathrm{NaCl}$ per 3 days. Leaves from control and stressed plants were harvested after 6 and $24 \mathrm{~h}$ (after reaching the concentration of $100 \mathrm{mM} \mathrm{NaCl}$ ). Plants were also harvested after $48 \mathrm{~h}$ recovery from salt. All samples were immediately frozen in liquid nitrogen and stored at $-80^{\circ} \mathrm{C}$ until use for RNA purification and expression analysis. In parallel to this assay, a drought stress experiment was conducted, in which, Razegui cultivar was grown in pots under controlled greenhouse conditions. No irrigation was applied to Razegui grapevines during 3 weeks upon which plant material was sampled.

2.2. Isolation of Total RNA and Northern Blot Analysis. Total RNAs were isolated from fully developed leaves collected from stressed and control plants according to Daldoul et al. [16]. Differential regulation of $V v M A P$ kinase cDNA was validated using northern blot analysis. Glyoxylated total RNAs $(10 \mu \mathrm{g})$ from control and stressed leaves were separated in $1.2 \%$ MOPS (3-(N-morpholino) propanesulfonic acid) agarose gel electrophoresis and blotted by capillary transfer on nylon membranes (Hybond N, GE Healthcare Europe $\mathrm{GmbH}$, Munich, Germany). Hybridisations were performed at $65^{\circ} \mathrm{C}$ in phosphate-SDS-EDTA buffer using $\alpha-\left[{ }^{32} \mathrm{P}\right]-$ dCTP-(3000 Ci/mmole) labelled cDNAs probes prepared with the HexaLabel DNA Labelling Kit (Fermentas, St. LeonRot, Germany) according to the manufacturer's instructions. cDNA probes were encoding for MAP kinase SSH clone (GenBank accession no. GH717878.1) and 26 rRNAs (GenBank accession no. GO307585, as loading control gene). Those probes were obtained by purification of clones' sequences. After hybridization, membranes were washed with decreasing stringency up to $0.2 \mathrm{x}$ SSC and $1 \%(\mathrm{w} / \mathrm{v})$ sodium duodecylsulfate at $65^{\circ} \mathrm{C}$. Membranes were exposed to Kodak BioMax MS X-ray films (Sigma Aldrich) for up to $72 \mathrm{~h}$. Assays were repeated twice using samples from independent experiments.

\section{Results}

In this study, we focused on the expression analysis of the $V v M A P$ kinase clone isolated from the differential screening

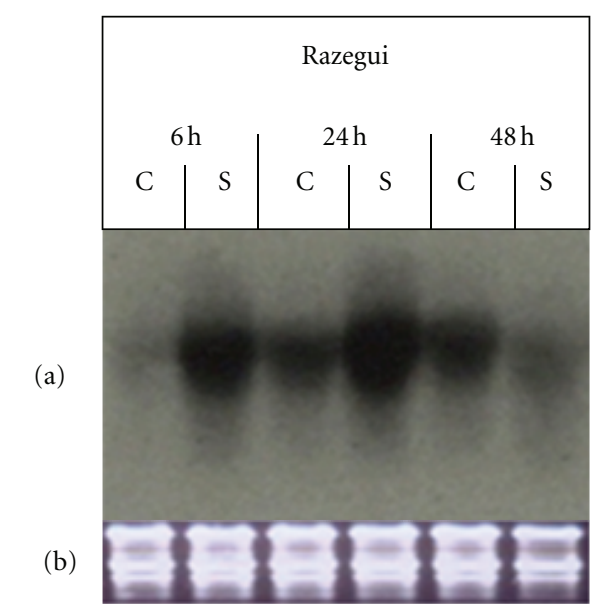

FIGURE 1: RNA gel blot analysis for VvMAP kinase cDNA regulated by salt stress. Transcript abundance was evaluated in the leaves material of Razegui cultivar. Each lane contained $10 \mu \mathrm{g}$ of total leaf RNA. (a) C: Control, S: Stressed, $6 \mathrm{~h}$ or $24 \mathrm{~h}$ after $100 \mathrm{mM} \mathrm{NaCl}$ treatment, $48 \mathrm{~h}=48 \mathrm{~h}$ of recovery from salt stress. (b) The Et-Brstained agarose gel of total RNAs is shown as a loading control.

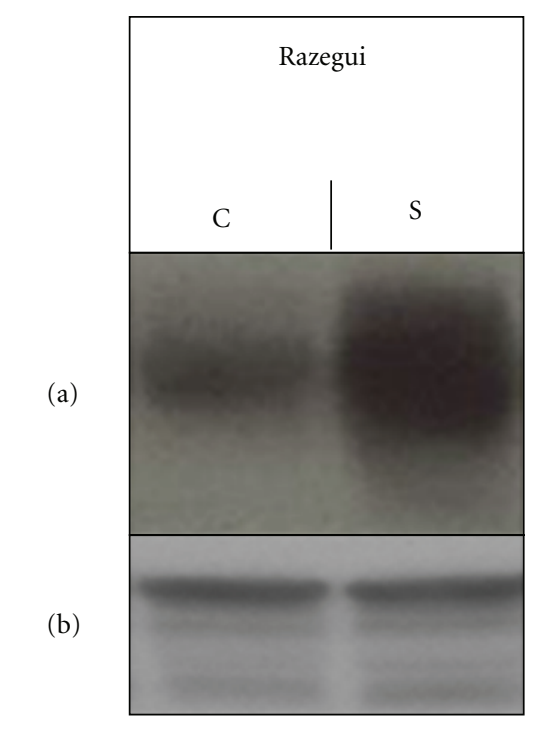

FIGURE 2: Differential regulation of VvMAP kinase cDNA under water deficiency. (a) Identical amounts of RNAs were denaturated by glyoxylation and subjected to electrophoresis on $1.2 \%$ agarose gels. Transcript abundance was evaluated in the leaves material of Razegui cultivar. Each lane contained $10 \mu \mathrm{g}$ of total leaf RNA. C: control, S: 3 weeks of water deficiency. (b) 26 S RNA gene used as an internal control for equal loading.

of SSH Libraries [17]. The regulation of this gene by osmotic stress was characterised by means of Northern hybridisation. As a control, a $26 \mathrm{~S}$ ribosomal RNA gene was hybridized in parallel for equal loading of RNA samples and was clearly not affected by stress treatment when control and stressed leaves were compared (Figure 2(b)). The $V v M A P$ kinase transcript was upregulated in the tolerant cultivar Razegui within $6 \mathrm{~h}$ and its expression increased after $24 \mathrm{~h}$ of salt treatment (Figure 1(a)). On the other hand, the expression level of 
the transcript was downregulated after additional $48 \mathrm{~h}$ stress recovery. To analyse whether MK5 is activated by drought, grapevine plants were exposed to a severe water stress. This gene was also found to be differentially expressed in Razegui cultivar (Figure 2(a)). Homology search of VvMAP kinase (accession no. GH717878.1) using Blast program [18] showed that this transcript shares a high sequence identity (96\%) with Protein kinase MAP Kinase 5 of the halophyte plant Mesembryanthemum (accession no. AF234652.1). This high identity level would indicate that this gene could confer a stress tolerance in grapevine.

\section{Discussion}

The comparative effects of salinity and drought on plants were largely discussed $[19,20]$ as both stresses induce osmotic changes in plant cells.

In this study, we specifically targeted the early responsive genes involved in stress signaling response. In this context tissues were sampled for expression analysis from control and stressed plants at three time points $(6,24$, and $48 \mathrm{~h})$. Salt was applied for a short-term period ( $6 \mathrm{~h}$ and $24 \mathrm{~h}$ ) after reaching the final salinity level of $100 \mathrm{mM}$ to enrich the library with early responsive genes involved in stress response and signals transductions. We focused on the expression pattern of a specific cDNA encoding an MAP kinase which could be involved in stress signal transduction. In fact, the induction of $V v M A P$ kinase gene by abiotic stress was shown in rice and its overexpression conferred tolerance to drought and salt stress [2]. The decrease of the expression level of $V v M A P$ kinase after $48 \mathrm{~h}$ of recovery indicates that its activation is specifically linked to the stress condition. These results are in accordance with several reports. In fact, recently, several plant protein kinases were found to be activated by osmotic stress [21]. The idea that an MAPK is involved in osmotic stress adaptation might find support in the report where the pea PsD5 MAPK was shown to complement HOG1-deficient yeast for their ability to grow on a hyperosmolar medium [22].

The overexpression of MAPK gene expression by salt and drought stresses could be an indicator for its function in signal transduction. The $V v M A P$ kinase could be good candidate to study the mechanism of signalling pathways in grapevines.

\section{Conclusion}

This study demonstrates a differential expression of $V v M A P$ kinase cDNA gene in response to osmotic stress in grapevine. This EST was suggested to be involved in the signalling pathway during osmotic stress. Thus, it would be interesting to get its corresponding full-length sequence, in order to analyze its precise function in osmotic stress tolerance in grapevines. This gene would contribute to a better understanding of the molecular mechanisms of signal transduction pathways, which could lead to improve grapevine stress tolerance.

\section{Acknowledgments}

This work was funded in part by the International Centre for Genetic Engineering and Biotechnology (ICGEBCRP/TUN06-01). S. Daldoul was also supported by a research grant of the German Academic Exchange Service (DAAD).

\section{References}

[1] S. J. Neill and E. C. Burnett, "Regulation of gene expression during water deficit stress," Plant Growth Regulation, vol. 29, no. 1-2, pp. 23-33, 1999.

[2] J. K. Zhu, "Salt and drought stress signal transduction in plants," Annual Review of Plant Biology, vol. 53, pp. 247-273, 2002.

[3] K. Gomi, D. Ogawa, S. Katou et al., "A mitogen-activated protein kinase NtMPK4 activated by SIPKK is required for jasmonic acid signaling and involved in ozone tolerance via stomatal movement in tobacco," Plant and Cell Physiology, vol. 46, no. 12, pp. 1902-1914, 2005.

[4] M. Mayrose, A. Bonshtien, and G. Sessa, "LeMPK3 is a mitogen-activated protein kinase with dual specificity induced during tomato defense and wounding responses," The Journal of Biological Chemistry, vol. 279, no. 15, pp. 14819-14827, 2004.

[5] L. Bögre, W. Ligterink, I. Meskiene et al., "Wounding induces the rapid and transient activation of a specific MAP kinase pathway," Plant Cell, vol. 9, no. 1, pp. 75-83, 1997.

[6] M. Lalle, S. Visconti, M. Marra, L. Camoni, R. Velasco, and P. Aducci, "ZmMPK6, a novel maize MAP kinase that interacts with 14-3-3 proteins," Plant Molecular Biology, vol. 59, no. 5, pp. 713-722, 2005.

[7] D. Takezawa, "Elicitor- and A23187-induced expression of WCK-1, a gene encoding mitogen-activated protein kinase in wheat," Plant Molecular Biology, vol. 40, no. 6, pp. 921-933, 1999.

[8] M. L. W. Knetsch, M. Wang, B. Ewa Snaar-Jagalska, and S. Heimovaara-Dijkstra, "Abscisic acid induces mitogen-activated protein kinase activation in barley aleurone protoplasts," Plant Cell, vol. 8, no. 6, pp. 1061-1067, 1996.

[9] T. K. Hyun, J. S. Kim, S. Y. Kwon, and S. H. Kim, "Comparative genomic analysis of mitogen activated protein kinase gene family in grapevine," Genes and Genomics, vol. 32, no. 3, pp. 275-281, 2010.

[10] G. P. Chen, W. S. Ma, Z. J. Huang, T. Xu, Y. B. Xue, and Y. Z. Shen, "Isolation and characterization of TaGSK1 involved in wheat salt tolerance," Plant Science, vol. 165, no. 6, pp. 13691375, 2003.

[11] F. Cellier, G. Conéjéro, J. C. Breitler, and F. Casse, "Molecular and physiological responses to water deficit in drought-tolerant and drought-sensitive lines of sunflower," Plant Physiology, vol. 116, no. 1, pp. 319-328, 1998.

[12] L. Hamrouni, F. Ben Abdallah, C. Abdelly, and A. Ghorbel, "Evaluation de la tolérance au sel chez les vignes tunisiennes cultivées in vitro," in Poceedings du XXVIIème Congrès Mondial de la Vigne et du Vin, pp. 102-112, Bratislava, Slovakia, June 2002.

[13] I. Toumi, M. Gargouri, I. Nouairi et al., "Water stress induced changes in the leaf lipid composition of four grapevine genotypes with different drought tolerance," Biologia Plantarum, vol. 52, no. 1, pp. 161-164, 2008. 
[14] I. Toumi, P. N. Moschou, K. A. Paschalidis et al., "Abscisic acid signals reorientation of polyamine metabolism to orchestrate stress responses via the polyamine exodus pathway in grapevine," Journal of Plant Physiology, vol. 167, no. 7, pp. 519$525,2010$.

[15] S. Daldoul, S. Chenenanoui, A. Mliki, and M. Höfer, "Improvement of an RNA purification method for grapevine (Vitis vinifera L.) suitable for cDNA library construction," Acta Physiologiae Plantarum, vol. 31, no. 4, pp. 871-875, 2009.

[16] S. Daldoul, S. Guillaumie, G. M. Reustle et al., "Isolation and expression analysis of salt induced genes from contrasting grapevine (Vitis vinifera L.) cultivars," Plant Science, vol. 179, no. 5, pp. 489-498, 2010.

[17] S. F. Altschul, W. Gish, W. Miller, E. W. Myers, and D. J. Lipman, "Basic local alignment search tool," Journal of Molecular Biology, vol. 215, no. 3, pp. 403-410, 1990.

[18] H. J. Bohnert and J. C. Cushman, "Plant and environmental stress adaptation strategies," in Plant Biotechnology and Transgenic Plants, K.-M. Oksman-Caldentey and W. H. Barz, Eds., pp. 635-664, Marcel Dekker, New York, NY, USA, 2002.

[19] R. Munns, "Comparative physiology of salt and water stress," Plant, Cell and Environment, vol. 25, no. 2, pp. 239-250, 2002.

[20] L. Xiong and Y. Yang, "Disease resistance and abiotic stress tolerance in rice are inversely modulated by an abscisic acidinducible mitogen-activated protein kinase," Plant Cell, vol. 15, no. 3, pp. 745-759, 2003.

[21] C. Jonak, S. Kiegerl, W. Ligterink, P. J. Barker, N. S. Huskisson, and H. Hirt, "Stress signaling in plants: a mitogen-activated protein kinase pathway is activated by cold and drought," Proceedings of the National Academy of Sciences of the United States of America, vol. 93, no. 20, pp. 11274-11279, 1996.

[22] B. Pöpping, T. Gibbons, and M. D. Watson, "The Pisum sativum MAP kinase homologue (PsMAPK) rescues the Saccharomyces cerevisiae hog1 deletion mutant under conditions of high osmotic stress," Plant Molecular Biology, vol. 31, no. 2, pp. 355-363, 1996. 

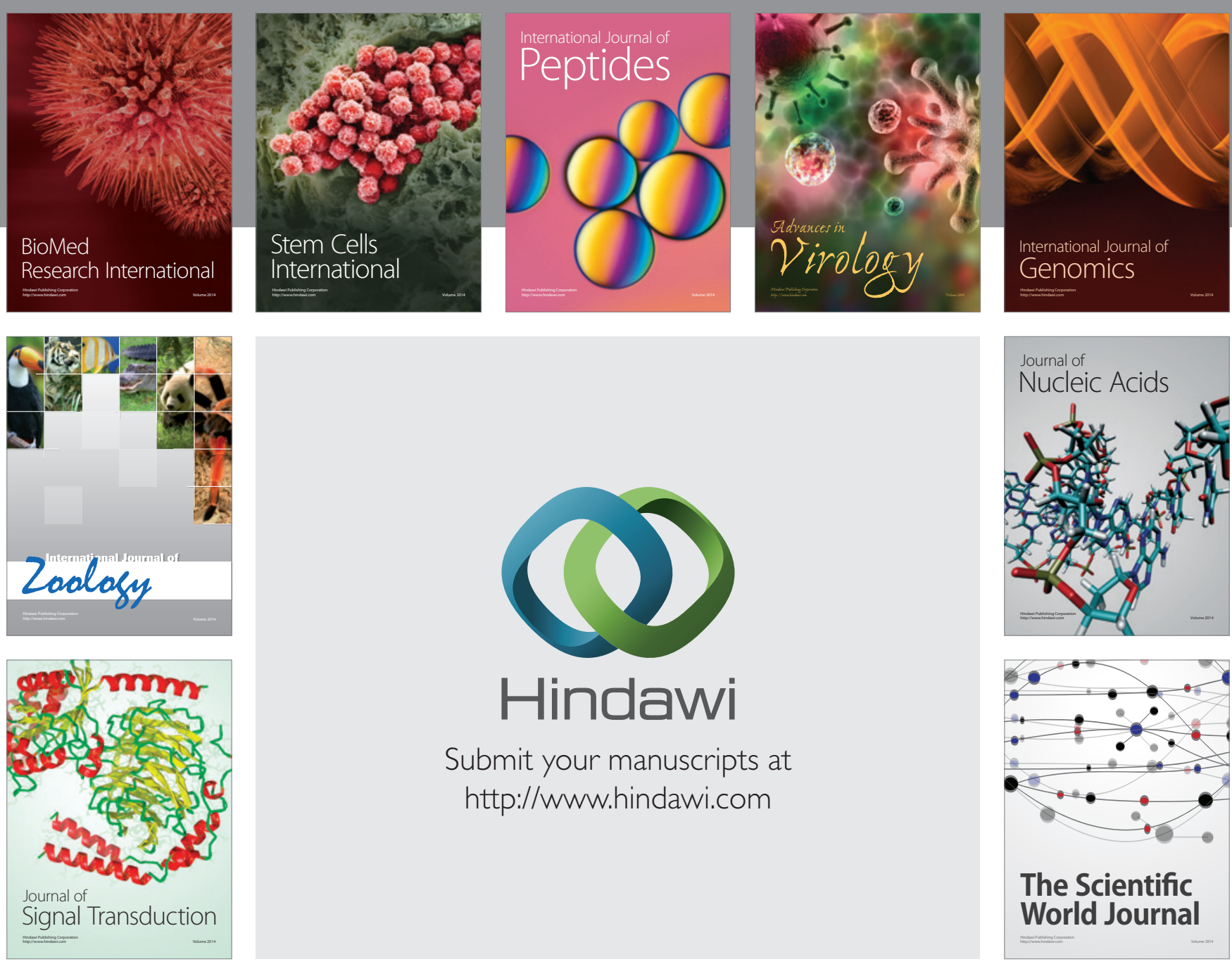

Submit your manuscripts at

http://www.hindawi.com
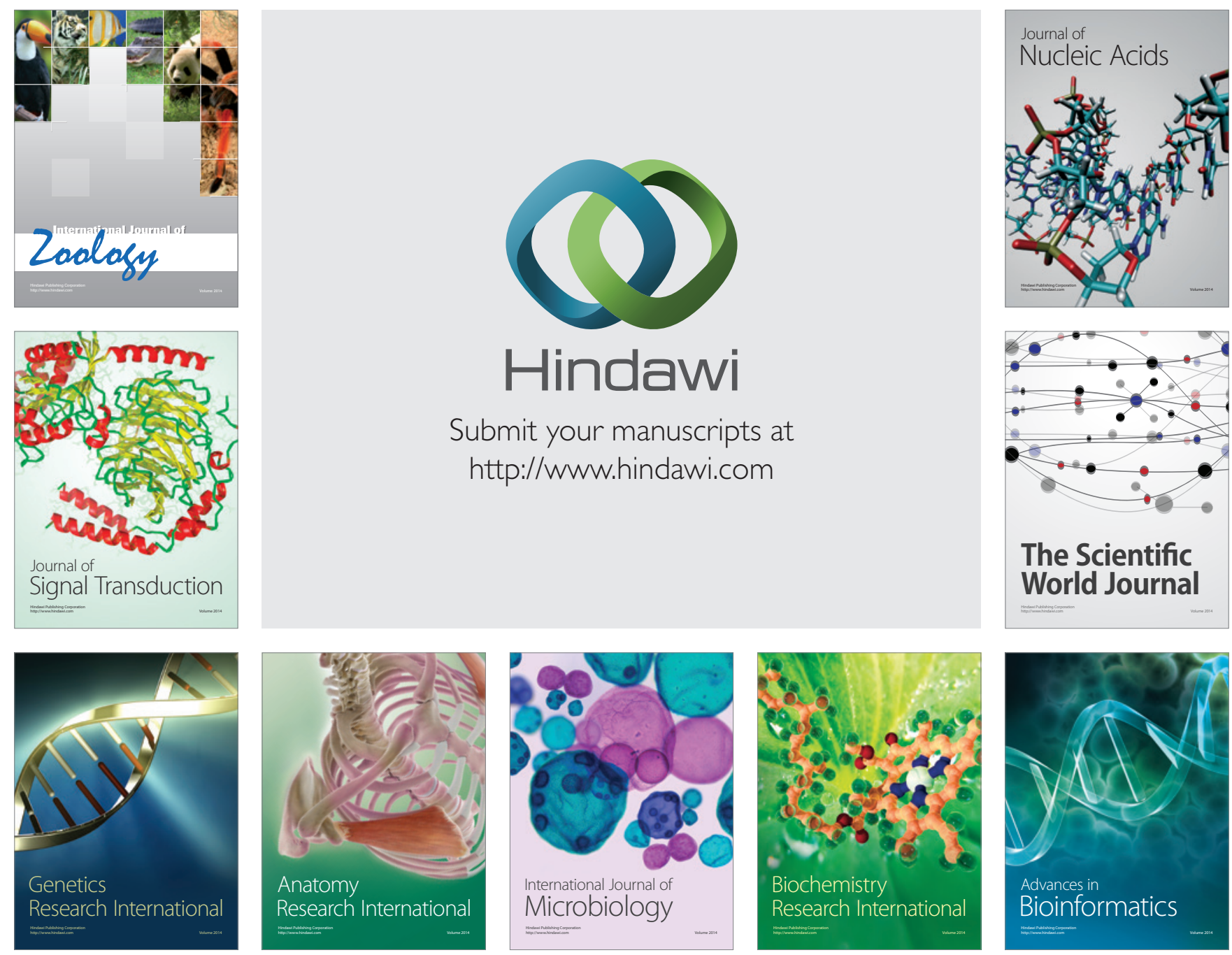

The Scientific World Journal
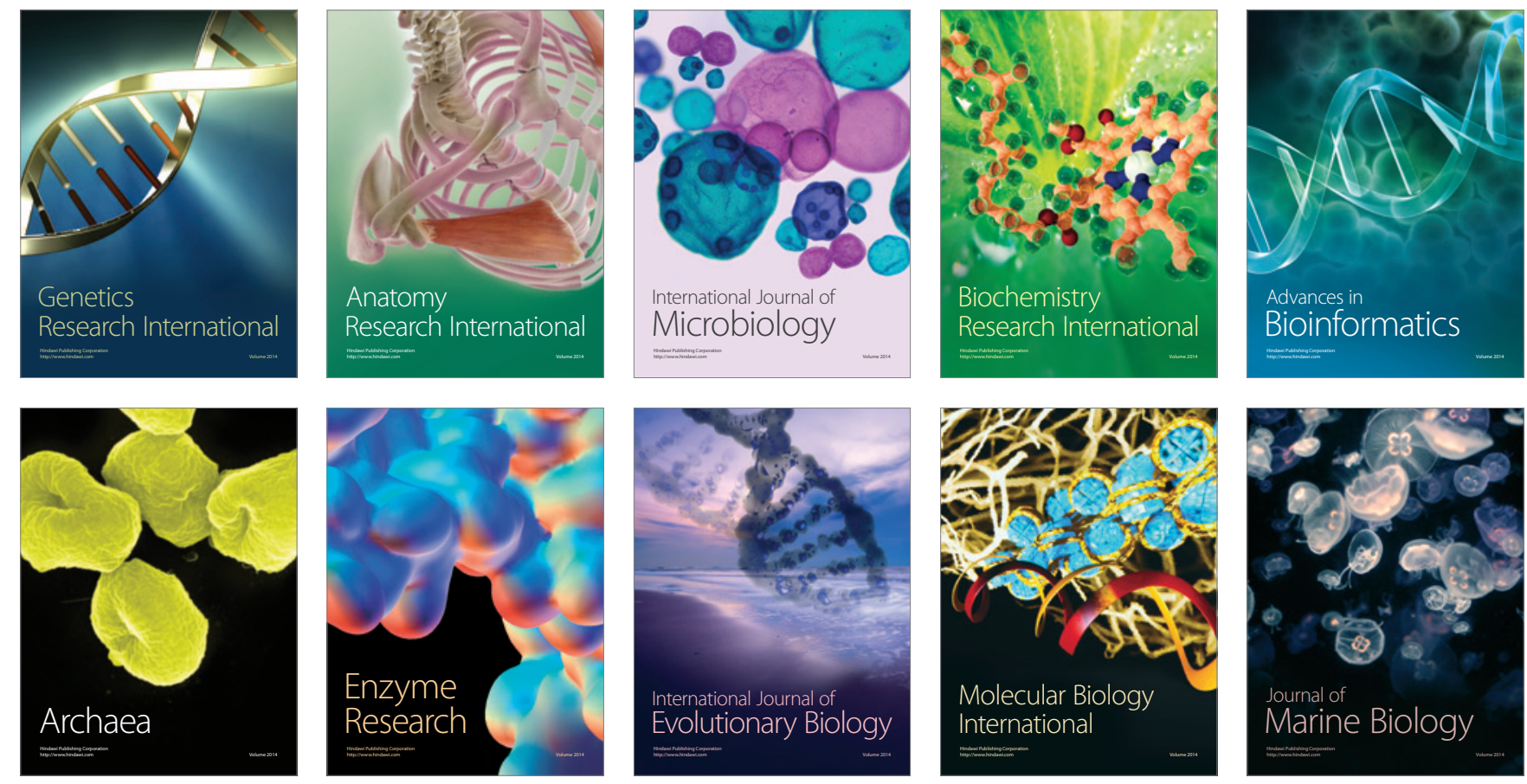